\title{
Like Braiding Sweetgrass
}

Nurturing Relationships and Alliances in Indigenous Community-based Research

\author{
Janice M. Victor, Linda M. Goulet, Karen Schmidt, \\ Warren Linds, Jo-Ann Episkenew, and Keith Goulet
}

\begin{abstract}
The shifting environment of Indigenous community-based research demands reflexivity because the negotiation and maintenance of relationships are central (Findlay, Ray, \& Basualdo, 2014). This paper expands on the importance of social relationships in the Nehinuw (Cree) worldview by reflecting on an ongoing research partnership among a team of Indigenous and Settler researchers from three universities and one Indigenous community agency. The Nehinuw relationships of weechihitowin (supporting and helping each other), weechiyauguneetowin (partnership, collaborative or shared action), otootemitowin (respectful openness and acceptance of others), and weechiseechigemitowin (alliances for common action) (L. Goulet \& K. Goulet, 2014) form the theoretical framework for analyzing the challenges and successes that have sustained this collaboration for almost 10 years. This article will enhance understanding of Indigenous community-based research to promote an epistemological shift toward Indigenous modes of inquiry.
\end{abstract}

Keywords: community-based research, collaboration, decolonization, Indigenous research

The sweetest way [to braid sweetgrass] is to have someone else hold the end so that you can pull gently against each other, all the while leaning in, head to head, chatting and laughing, watching each other's hands, one holding steady while the other shifts the slim bundles over one another, each in its turn. Linked by sweetgrass, there is reciprocity between you, linked by sweetgrass, the holder as vital as the braider. (Kimmerer, 2013, p. ix)

In many Western research practices, there is a power imbalance that has become normalized, creating a hierarchy in which those with expertise are situated at the top 
while the research subjects sit passively at the bottom. Within this paradigm, the expertise of those low in the hierarchy is often invalidated, leaving research participants, typically labelled "subjects," with little to no input into that to which they are subjected. Such has too often been the situation with the vast majority of research with Indigenous peoples and their communities (Ball \& Janyst, 2008; Findlay, Ray, \& Basualdo, 2014; Smith, 1999; Styres, Zinga, Bennett, \& Bomberry, 2010; Tobias, Richmond, \& Luginaah, 2013). Even now with the recognition of this power imbalance articulated in Chapter 9 of the Canadian Tri-Council Policy Statement 2 on research involving First Nations, Inuit, and Métis people (Canadian Institutes of Health Research, 2014), community-based research with Indigenous communities is too often viewed from the perspective of Western knowledge traditions. Such epistemic discrimination (Allen \& Smylie, 2015) subtly replicates colonial relationships and practices in research.

Research that is decolonizing serves to interrogate long-held assumptions of Western expertise and superiority, deconstruct practices, reveal systemic discrimination and power imbalances, and reconstruct the same in a more equitable manner that respects the expertise of Indigenous peoples. Recognizing and centralizing Indigenous knowledges, understandings, and expertise in community-based research Indigenizes and decolonizes research methods. In so doing, power shifts to a more balanced approach that recognizes the understandings of Indigenous peoples and builds the capacities of Indigenous communities to self-determine (Smith, 1999). Many Indigenous philosophies arise through a relational epistemology where understandings of the world are constructed through the lens of interconnectivity with our social and physical environments (L. Goulet \& K. Goulet, 2014; Healy \& Tagak, 2014). This recognition of our interconnectivities translates into a relational accountability where the implications of all activity are considered so that actions honour individuals, the community, the spiritual world, and the environment (Absolon, 2011; Wilson, 2008).

Relational epistemology and accountability situate relationships as the foundation of ethical research with Indigenous peoples. Relationships are formed, nurtured, and reformed throughout the research process in genuine respect and appreciation, preferably with the aim of forming lasting bonds between researchers and community (Ball \& Janyst, 2008; Findlay et al., 2014; Fletcher, 2003; Styres et al., 2010; Tobias et al., 2013). Tobias et al. (2013) have discussed how they approach their research collaborations with an attitude of cultural humility that requires non-Indigenous researchers to practice reflexive awareness to recognize their own positions of power while making conscious efforts to rebalance the power dynamic. The focus of relationship building is on learning, not prejudging or predetermining, what will be 
effective for a community. This sort of deliberate reflection and communication can address the imbalance of colonial methods and ensure that primary stakeholders and members of Indigenous communities have an equal role in decision-making (Ball \& Janyst, 2008; Fletcher, 2003; Styres et al., 2010; Tobias et al., 2013) and in the research process. In community-based research, a collaboration that decolonizes occurs when there is sharing of respect, knowledge, and leadership.

This paper builds on the importance of social relationships in Nehinuw (Cree) philosophy by reflecting on an ongoing research partnership between a team of Indigenous and Settler researchers from three universities and one Indigenous community agency. The Nehinuw relationships of weechiseechigemitowin ${ }^{1}$ (alliances for common action), otootemitowin (respectful openness and acceptance of others), weechiyauguneetowin (partnership, collaborative or shared action), and weechihitowin (supporting and helping each other; L. Goulet \& K. Goulet, 2014) form the theoretical framework for analyzing the interactions between and among a research team, along with the challenges and successes that have sustained this collaboration for almost 10 years. This article will enhance understandings of Indigenous community-based research methods to promote an epistemological shift toward Indigenous modes of inquiry.

Interactivity is a central concept in Nehinuw thought (L. Goulet \& K. Goulet, 2014). Developing and sustaining the relationships within the research team is an integral part of Indigenous methods. Because our research project is communitybased, we have various relationships with different stakeholders: the funders, the tribal council, the research team, the Indigenous tribal council's health services, and the youth in the different communities. In this paper, we focus on the first six years of our multiyear partnership as well as on the partnership between and among the research team and the community partner. We examine our practice through the lens of Nehinuw concepts of social relationships to bring Indigenous ways of being into our reflection and to guide our future practice. The phrase "braiding the sweetgrass" provides an apt evocation of our collaborative research process that involves reciprocal relationships between community and university, between research and Indigenous ways of being, and between conventional and arts-based forms of research and intervention. We will use the elements of Nehinuw thought to name the strands of our work and braid them together throughout this article.

\section{The Project Environment}

In 2005, researchers and community members in Saskatchewan, Canada, were discussing the connection between some recent Indigenous youth suicides and the 
dispirited malaise their peers were experiencing. Through this loose collection of individuals who either knew, or knew of, one another, this conversation was transformed into a successful health research grant application to use the arts as both a research methodology and a strategy to help Indigenous youth examine how their decisions affected their health. With this grant, a team of researchers from the First Nations University of Canada and Concordia University entered into a research partnership with File Hills Qu'Appelle Tribal Council (FHQTC) Health Services. The research team represented a diverse group of First Nations, Métis, and nonIndigenous individuals who held personal and professional connections to the FHQ Indigenous community. The community member on this research team was the health educator with FHQTC Health Services, which provides services for 11 First Nations in southern Saskatchewan. These communities are composed of Nehiyaw (Cree - Y dialect), Anishnabe/Nagawe (Saulteaux), Dakota, Nakota, and Lakota people. Our target demographic was youth between the ages of 12 and 20. Participants were originally recruited in partnership with FHQTC Health Services and schools situated on the participating First Nations. Community-specific workshops were delivered at the schools while multischool workshops were delivered at more central locations.

The focus of our work over the years has been participatory arts-based research that uses artistic tools and processes and artistic expression as a way to understand, enhance, and explore individual and collective experiences (Jones et al., 2008; Knowles \& Cole, 2008; McNiff, 1998). Community-based arts research has community and public space at the heart of research practice (Barndt, 2009) so that inquiry methods engage participants in all stages of the research process aimed at producing practical knowledge that benefits the community. Bishop (2011) named Whakawhanaungatanga as a Māori research approach that identifies, "through culturally appropriate means, your bodily linkage, your engagement, and, therefore, an unspoken but implicit commitment to other people" (p. 203). An important finding early in this project revealed that arts-based methods are particularly useful for exploring topics that relate, directly or indirectly, to the body, particularly health and wellbeing (Ritenburg et al., 2014). Aluli Meyer (2008) wrote that the "body is the central space in which knowing is embedded" (p. 223) and "knowing is embodied and in union with cognition" (p. 224). In the Nehinuw worldview, the focus on understanding is achieved through action and interaction in its various forms, including physical, spiritual, emotional, social, or cognitive activity (L. Goulet \& K. Goulet, 2014). Applied theatre is a holistic approach that requires participants to use all domains in their actions and interactions. Thus, arts-based methods, such as applied theatre, 
have been increasingly used with great success as intervention activities for a variety of health issues and behaviours (Rossiter et al., 2008; Skingley, Bungay, \& Clift, 2012).

\section{Nurturing Relationships and Alliances in Community-based Research}

Using Nehinuw terms serves to Indigenize our thinking about our research. Because these terms emphasize equity and the retention of self-authority, they also serve to guide the decolonization of our future research practice. We use the Nehinuw concepts of weechiseechigemitowin (alliances for common action), otootemitowin (respectful openness and acceptance of others), weechiyauguneetowin (partnership, go along with), and weechihitowin (supporting and helping each other; L. Goulet \& K. Goulet, 2014) to reflect on the relational processes that feed our collaboration. In this article, we draw upon a team interview conducted in 2011 with the early partners in the project. Facilitated by our project's then postdoctoral fellow, Dr. Nuno Ribeiro, the participants included the four founders of the project, Drs. Jo-Ann Episkenew, Linda Goulet, and Warren Linds and community health educator Karen Schmidt; doctoral student Heather Ritenburg; and the community research assistant, Allison Whiteman.

\section{Weechiseechigemitowin: Alliances for Common Action}

The ideas of interaction, collaboration, cooperation, reciprocity, and sharing are important aspects of Nehinuw thought (L. Goulet \& K. Goulet, 2014). Weechiseechigemitowin is a concept of forming an alliance to achieve a common goal. The middle stem, oseechige, means to actively create while ito designates interactivity. The creative action is done together, in interaction with one another, without subsequent loss of autonomy. In addition to being a political goal of First Nations, selfdetermination is an important feature of Nehinuw thought that manifests in weechiseechigemitowin. For example, self-determination for an individual is inherent in the term atitipenimisowin, which describes the process of a young person coming to have measured authority over oneself as they learn how to make decisions and take action more independently. The Nehinuw see self-determination as the ability to exercise authority over oneself as a person, a group, a community, a nation, or a people (L. Goulet \& K. Goulet, 2014). The Māori people have similar concepts, as Bishop (2011) has explained.

Self-determination... [is] the right to determine one's own destiny, to define what that destiny will be and to define and pursue means of attaining that 
destiny. However, there is also a clear understanding among Māori people that such autonomy is relative, not absolute, that it is self-determination in relation to others. (p. 32)

In weechiseechigemitowin, people may have different perspectives, but they join together to change and accomplish something without giving up their authority over themselves. They enter into the interactive situation so they can share and draw upon each other's knowledge and resources. Leadership is not designated by external authority or by a designated role or title but rather by consent or agreement between the participants, whether implicit or explicit. Nehinuw scholar Keith Goulet (L. Goulet \& K. Goulet, 2014) has coined the term co-determination, which is based on the Nehinuw concept of weechiseechigemitowin when two self-determining entities form an agreement to come together to achieve a goal without either party dominating the other. In co-determination, equity is expected as parties share power and resources as they work together. In our project, weechiseechigemitowin took place with the political leadership of the tribal council and the university.

The project was formalized with a research agreement between the FHQ Tribal Council and our core research team. In prioritizing scarce resources for FHQ Health Services staff to work on, the tribal council had identified youth as a priority area. This coincided with Linda's desire to put forward a grant application to initiate a theatre project to address the low spirits and high suicide rates in some of the First Nation communities. We proposed to work with the Indigenous youth using the arts to have them examine their decision-making around issues of sociocultural health. With a common goal, each party - the university and the tribal council - wanted to draw upon our collective knowledge and resources to improve the health of the FHQ youth.

The health educator, Karen Schmidt, was a key resource in our research provided by the FHQ Tribal Council. Her knowledge of the communities and her network of relationships with the schools in the area were central to the success of the research. Having often worked in First Nations schools, Karen had built relationships with the youth, the educators, and the decision makers in the communities. She brought to the research team access to her network of relationships within the tribal council health services and with the youth and staff throughout the FHQ territory. In addition to the access to funding for health research, the university researchers brought their knowledge of incorporating Indigenous methods into the research process. Weechiseechigemitowin allowed each party in the agreement to share their knowledge and resources with the other to create a synergy that was greater than the sum of the two parts, with no participant dominating the other. 


\section{Otootemitowin: Respectful Openness and Acceptance of Others}

Openness to others' perspectives, approaches, and practices combined with ongoing communication and respectful, knowledge sharing are necessary in communitybased research with Indigenous communities (Ball \& Janyst, 2008; Findlay et al., 2014; Fletcher, 2003; Styres et al., 2010; Tobias et al., 2013). In Nehinuw thought, otootemitowin translates as being open to and accepting of others (L. Goulet \& K. Goulet, 2014), and it is vital for building any alliance between Indigenous and non-Indigenous partners. It means paying attention to and becoming familiar with other ways of doing things, particularly cultural ways of conducting affairs. For example, after we signed the research agreement and received our funding, before we engaged in research activities we sought out the elder who worked for FHQ health and offered him cloth and tobacco to ask him to conduct a pipe ceremony so the process could start in a good way, a way that was recognized by, and followed, the protocol of the FHQ Tribal Council. Other elders and community members were invited to participate in this ceremony.

Otootemitowin can lead to decolonized relationships that acknowledge and respect different ways of knowing. Openness is a characteristic that helps to overcome the sense of superiority inherent in Eurocentric thought that supports research practices where one way of being is dominant. Instead, otootemitowin guides participants to be open to recognizing the strengths and gifts of others while being patient and accepting of other ways of being. Often this means that participants are required to work in ways different from their norm, ways with which they may not be comfortable.

Communication style is one such example. Whereas university communications tend to focus on the task, in many Indigenous communities visiting is an important aspect of life (L. Goulet \& Aubichon, 1997). Thus, communication is more about connecting with people and stems from a relational epistemology that tends to characterize Indigenous ways of being (Healy \& Tagak, 2014). Personal storytelling is part of how relations are developed and maintained. These Indigenous forms of communication, often seen as frivolous or optional in university communication, connect us on a human level, outside our designated roles and the real or perceived positions of power and status (Episkenew, 2011). At the university, it is often the norm to jump into discussions to ensure your point is heard and made. In some Indigenous communication styles, it is more appropriate to listen to others and wait until there is a pause before speaking. To some Indigenous peoples, silence in a discussion means that people are thinking about an issue, so it is appropriate to wait and think about one's own perspective in light of what others have said before speaking. 
Otootemitowin is a key feature of shared leadership, a concept we reflect upon shortly, because it emphasizes the value of being open to others. Being open to another can lead to deep listening for the purpose of understanding, which is an important component in Nehinuw thought.

The Nehinuw word for knowledge is kiskeneetumowin. The meaning of the root stem kisken- is to know. However, in Cree it is understanding that is emphasized. The Nehinuw word nisitootumowin encapsulates both the English concepts of meaning and understanding and is a central concept in learning. In the Nehinuw view, knowledge acquisition is not enough. Knowledge needs to be complemented with understanding. This Nehinuw concept of nisitootumowin (understanding and meaning) is interwoven with interaction, practice and action by doing. (L. Goulet \& K. Goulet, 2014, p. 59)

Otootemitowin can be linked to the Nehinuw word for listening in communication, n'dootumowin, which can have the connotation of listening without judgment. The value of listening to what is said and not said cannot be overstated because words may be laden with different meanings and implications leading to inaccurate assumptions (Fletcher, 2003; Styres et al., 2010). In our team interview, Jo-Ann reflected on how a particular training program in interest-based negotiations aligned with openness and acceptance in both communication and leadership.

Jo-Ann: It's a thing... where you have to listen and acquire empathy. You have to hear the other person's needs. ... It's about empathy. It's about listening, about understanding and collaborating, compromising. ... It resonated with my own belief system, and I think that people who are in leadership positions are servants, you know.... Whether you're in a university administrator [position] or what, you're there to serve the other people who are doing important work.

Otootemitowin is a concept that guides our research work with the youth participants as well. Because the drama method we use is creative, otootemitowin reminds us to be open to the students' representations of their experiences. They tell the stories of their lived experiences in our workshops through the creation of tableau called Image Theatre in which participants use their bodies to form static images to tell a moment of the story (Linds \& Vettraino, 2008). Although as facilitators we may set a broad theme for students to consider, the students determine the content of their story. For example, when we have asked them to create a tableau of the main health issues facing youth in their community, they showed scenes of drinking at a party, fighting, or car accidents resulting from partying. Allison's observations demonstrate how 
openness and acceptance transforms our work from research on youth wellness to research (Absolon, 2011) with youth about their wellness.

Allison: The workshop process is very much like our collaborative research group. When we go into the workshops, we're not there to teach the kids something. We're creating a relationship with them. It . . creates that space where the kids are learning about themselves. They can learn something about us, and together we learn something about the world in which we all inhabit. It's in those relationships that that happens. So it's not like going out and telling them something, it's about creating those relationships.... In the workshop the facilitators create something that's more equitable so we can be more open with and learn about and with one another. But I like the idea of searching with, because I think to me that would describe the research that we do.

Practicing otootemitowin translates into proceeding with humility, checking your assumptions, and not letting your ego interfere with learning different ways of seeing, thinking, and acting.

Jo-Ann: Working in an interdisciplinary team... I think you have to have a high tolerance for feeling stupid. ... When everybody is bringing a different set of skills and expertise to the table, we can't all know everything, so there's a certain humility required.... That is a requirement of this [work]: nobody gets to be the know-it-all, nobody gets to be the boss, because we all bring something different.

Moreover, there is a joy and relief to working this way. We do not need to feel insecure or defensive about our contributions because what we do give is valued rather than minimized or discounted. We feel listened to and respected, regardless of our role or contribution in the research. It is important with Indigenous communitybased research to have mechanisms to resolve instances of miscommunication (Ball \& Janyst, 2008; Fletcher, 2003). Our mechanism was simply the process of otootemitowin along with the attitude of weechihitowin (supporting one another).

Karen: It really helped knowing everyone before because when you work with a team and everyone has doctor in front of their name and yours doesn't, it could be intimidating. But knowing them and knowing that they were true equal partners was amazing for me, and I always felt very comfortable... Whenever there was a hard issue on something, I always used to be afraid to tell people what I thought, and I never ever felt... afraid to tell [our team] ... I always felt comfortable speaking from my heart. 
As team members, our goals are foremost to do work that resonates with the community and its needs. To do that, we practice otootemitowin where our meetings and other forms of communication are based on respect, inclusion, and equality.

\section{Weechihitowin: Supporting and Helping Each Other}

Weechiseechigemitowin (alliances) and weechiyauguneetowin (partnerships) depend on participants enacting weechihitowin (helping and supporting one another). Weechi-is to support or help another and is central to both of the former social-relational terms. Again, the medial stem ito indicates interactivity so the help or support is not unidirectional. It flows between and among the participants. Alliances and partnerships are built and sustained through the development of mutually supportive relationships.

Even at the beginning of our research, the researchers sought ways to support the work of the community without dominating the research process. The community research assistant worked with, and was supervised by, Karen at the FHQTC Health Services office. At the same time, Karen spread the word about the research project in the communities and connected the university researchers with potential youth participants. The university researchers made efforts to support the community partners by viewing the community from a strength-based perspective and identifying assets that can sometimes be overlooked. This approach supported the community by helping to illuminate what they already had: creativity, resourcefulness, love, and concern for those around them. As Heather observed in the group interview:

This project is not about studying a community and extracting anything from this community. It really is that the richness and the resources are in the community, and we're working to in some ways to ... just bring another lens to them, or bring another form of awareness to what those resources and strengths are.

Weechihitowin was foundational to our research practice. It reflected both our connection to the community and our stance in Indigenous research methods.

Jo-Ann: I am married into the community, so we've had workshops with kids who are my grandchildren as participants. It's not just this detached objective [stance]; it's personal. It's about helping these young people have a better life. We are journeying with the community in search of this knowledge and learning about better ways to work with the youth, things that will be helpful. But it's also the service of our community. It's not just about us and... going to come back to university and put 
this on my CV....It's about thinking about future generations having a better life. It's all about this community healing, so there's a responsibility.

We see the research as a way to help and support individuals and communities while engaging in a supportive learning journey together. Weechihitowin engenders the responsibility of those with resources to act with relational accountability (Wilson, 2008) and share those resources with others to support them in overcoming obstacles.

\section{Weechiyauguneetowin: Partnership as a Shared Journey}

Where weechiseechigemitowin (alliances) refers to broad-based coalitions, most often at the organizational level such as the one we have with the FHQTC, weechiyauguneetowin is the Nehinuw concept of partnerships on more of a one-to-one basis. In any alliance, it takes people working together to make them work. Weechiyauguneetowin has the connotation of equity and of journeying with one another. In the traditional lifestyle of hunting and trapping, your partner(s) accompany you on the hunt or live with you on the trapline. Mutual trust, interaction, and reliance on each other are key aspects of weechiyauguneetowin. In our work, we have found that in addition to the research agreement with the tribal council, our research team needed be partners with each other.

Often First Nations are working in underfunded and underresourced conditions, so it is often difficult to find a person from the community who has the expertise, interest, and time to devote to a research project. As previously mentioned, Karen has been an invaluable partner in our research as she has journeyed with us, taking part in almost all our workshops, participating in our team meetings, and hiring research assistants. With her expansive knowledge of the community, she contacted schools and Elders, advised university researchers on community conditions and needs, and was our eyes in the community for our activities and the sharing of our findings to different audiences.

Productive and ethical community-based research recognizes the gifts and strengths that everyone brings to the project (Styres et al., 2010; Tobias et al., 2013). In the group interview, the team identified how the collaboration really coalesced around the sharing of expertise and reliance on each other's skills, as is characteristic of weechiyauguneetowin.

Jo-Ann: Warren ... and Linda both knew about the theatre's work. ... I wanted to be part of the project and I knew how to get money [with grant writing]. 
Warren: Linda and I had been working on a public school system's anti-racism program, and we felt that the theatre process we used would be useful.

Heather: Jo-Ann and I . . crossed paths and ... had a chat, and Jo-Ann said, "What are you doing these days?" And I told her about my... master's research, which was arts-based research, and she immediately thought that I would have something to offer in terms of data analysis.

The skills that each team member brought to the partnership varied, but they all added strength to our work.

Weechiyauguneetowin (partnership) guides the interaction of the entire research team. We do not follow a hierarchical model inherent in many university research projects but strive to use a more equitable approach. The equity inherent in the term means that we use shared and situational leadership (Linds, Sammel, \& L. Goulet, 2013) where the context determines who the leader is, depending on their expertise and aptitude. The openness and acceptance of otootemitowin strengthens and supports the situational leadership of weechiyauguneetowin because it allows us to draw upon the resources and the strengths of all partners. For example, Warren's expertise is in the drama method that we use in our research workshops with youth, so he takes responsibility for the overall design and leadership of the workshops. Although each of us leads activities, we do so in consultation with Warren and Linda who, like Karen, are teachers experienced in working with Indigenous youth. Karen was also a skilled amateur photographer, so she took responsibility for collecting the photographic data during our workshops. As director of IPHRC, Jo-Ann has connections with an Indigenous health research network, so she keeps up to date on funding opportunities. Because she is in the office with our administrative staff, she also takes the lead in raising issues related to future research opportunities, finances, and expenditures.

Another example of how we practice situational leadership by using everyone's strengths is illustrated with a previous community research assistant who was embedded in the FHQTC Health Services office. She was well-organized and excellent in communicating with Elders and other professionals who worked with youth. At the same time, her experience in Indigenous youth leadership was through a program sponsored by the military, so it was very disciplined in its approach. In our workshops, she questioned why we did not just tell the youth what to do. While we recognized the benefits of each approach, our arts-based method of research called for the youth to be the researchers into their own lives where the interpretation of their stories remains with them, not with the facilitators. So rather than have her take 
on the leadership of the drama workshops, she organized meetings with community professionals and elders. These meetings informed the direction of the research as we learned more about the issues facing youth from the perspective of those who interacted with the youth on a daily basis.

In the following interview excerpt, the team reflected on the development of our weechiyauguneetowin (partnership) and the situational leadership approach that emerged from our journeying together.

Nuno: From my understanding of the project... it's a very democratic way of conducting a research project which seems to work remarkably well. Was it by common agreement? Was it because it worked? Was it because you knew each other previously?

Linda: I actually worked collaboratively in research for quite some time, but one of the first collaborative research projects I was involved in ... was supposed to be equal and collaborative, and yet wasn't. The power dynamics [because of the hierarchically structured university status designations] were just fascinating.... In this project, we seem to have a very organic team.... I think Warren and I got used to working in a distributed leadership format [prior to the partnership], so when we came to this research project, I think it was our way of working together. ... I think we brought that into this new venture, kind of our unspoken expectations.

Jo-Ann: I had experience in [shared leadership] from kind of a really different position.... I'd become acting academic dean at Saskatchewan Indian Federated College.... I had gone into the job knowing what [would] happen if somebody wasn't in there pushing the paper and getting things going. By December I knew ... that it was way more than just pushing paper. There was an opportunity... [to take] a course on collaborative leadership... and I went to this course.... And this whole idea resonated with my personal belief system.

Warren: I teach a course on group facilitation and leadership where I emphasize collaborative leadership, and I notice that students don't get that. They think it's too hard. They think either you're authoritarian or you're hands off, and they can't see that there's any other [leadership styles]. I'm constantly talking about that and trying to practice that in the way I teach, but [collaborative leadership] is not intentionally chosen. It's a very emergent kind of intuitive action.

Linda: I think that's part of how we tried to operate was to use everybody in the team [according to their] strengths. ... If there's anything conscious [in how we work], I think [it's] that at our meetings we do... recognize each other's strengths. 
In the above conversation, it is clear that our group views our diversity as a strength that makes us better together than what we could be working as individuals. Learning how to engage in collaborative and situational leadership can occur formally or informally, with difficulty or with ease, but in our case it was facilitated by our shared interest and commitment to changing health outcomes for Indigenous youth.

\section{The Centre(ing) Strand of the Braid: The Community Perspective}

Where the previous section comes from the university researcher perspective, this next section represents the community perspective of our collaboration. In it, Karen narrates her experience with our research partnership.

It all began with a phone call from Linda Goulet in 2005 with an invitation for FHQTC Health Services to partner on a project known as "Exploring Health Issues With Youth Through Drama." Because I was new to the position of health educator, I quickly jumped at the opportunity to include this project in my programming ideas. In this position, I was given the freedom to create a health education program that drew upon my skills as a teacher as long as the activities met the objectives of the tribal council, the needs of the community, and funding requirements. Thus began a 10-year partnership with Linda, Warren, and Jo-Ann to provide drama workshops to the youth in the FHQTC area. This situation was a win-win opportunity: FHQTC gained program enhancements, First Nation schools and communities were offered exciting activities, researchers were provided with participants and venues to learn what youth think about "health," and I got assistance with my program planning.

The project soon started bringing drama workshops to the schools. In the beginning, I was a learner alongside the youth participants. As I played the games, I soon overcame some of my own insecurities so I could truly understand how these activities could help the youth build self-confidence and overcome their shy feelings. I could relate and often shared in the opening circles how I felt I missed out on so much in life when I was young because I was so shy and afraid to put myself out there. It was in stepping outside the box that I learned to take risks and come out of my shell. I could see the parallels of my life and the young people we were working with. I could also see the opportunities they had if I could encourage them in a positive way. Finally, I could see how I might use these games in my work as health educator and share them with the rest of the team at FHQTC Health Services.

Every workshop over the years was different from the other and dependant on the age of the participants, their willingness to participate, and the environment or venue. 
Warren and Linda had experience with these types of workshops and had several days' worth of activities ready for any group. The leaders changed and adapted the activities to ensure participants felt comfortable with us and with each other, as well as feeling a sense of accomplishment. We were always negotiating what the researchers were hoping would result from the workshops and what the youth might obtain in return. I felt like I was the go-between, the middle strand of the braid, to ensure everyone enjoyed the experience.

As an educator, I understand how difficult it can be to lead the activity, assess the learners, and assess myself. I took on the role of watching the participants, noting a variety of responses: participation, resistance, excitement, respect, teasing, tiredness, boredom, and readiness to move on. The researchers were always respectful in the interactions. Youth were gently encouraged to participate if they seemed shy or "too cool" to join in. The amazing thing to watch was when those youth saw just how much fun the rest of the group was having, they silently joined the group. No one made a fuss or singled him or her out; they were just accepted back in. At each break, our team would discuss how things were going, what needed to change, and who would take different leads. Throughout each workshop, the team created an atmosphere of mutual respect and acceptance.

I felt my contribution to these workshops could be to take photos of participants in action and to remember the activities for my own use, but the research team felt the photos really told a story of how the youth may have felt during an activity. We came together to try to make sense of what we were seeing, and I was amazed at the emotions that came through in the photos: the pure joy, the bashful reluctance, the interest or disinterest, and the total excitement in trying something new and different.

Our team continues to meet on a regular basis, and Skype has been our best friend over the years. We are in various locations across Canada, and this has been a great way to keep our partnership and connection strong. One thing I have to say about our meetings is the way I learned how creative minds work. Many of our meetings lasted longer than the time allotted for them, mainly because we are all storytellers and the need to share those stories is strong. One item could spark several different stories that had to be shared. I always struggled between the need to get on with my other work and hear those important stories, but I often took on the facilitator role of moving us on to the next agenda item. Looking back, those stories were important to our understanding of our group, the community, and society. It reminds me of the way the elders tried to teach us, through stories that we may not have understood at the time but came to know later in life. That is how teaching works. 
Ifeel as though this partnership was meant to happen. Was it a coincidence that I knew Linda Goulet and Warren Linds from my previous educator role? What were the chances that Linda came to me because the first community she approached could not get leadership approval in time for the funding application to be submitted? How did Linda know I was in the middle of planning the health educator role and objectives when she made that call? How was I able to get FHQTC leadership approval, complete with signatures, in two days so the application could be submitted? I believe things happen as they are meant to, and I believe that is why this partnership has remained so strong for the past 10 years. I am eternally thankful for that call from Linda and for the friendships that have been created because of this partnership. As old friends are, we have the mutual respect to be honest with each other for the good of the participants and the future of the project.

\section{Challenges to Our Braiding: Colonial Ghosts Inherent in the Research}

Although we strive to enact our beliefs of otootemitowin (openness) and weechihitowin (supporting and helping each other) in our relationships of weechiyauguneetowin (partnership) and weechiseechigemitowin (alliances), community-based collaborative research is a human endeavour. We recognize that we are all social beings who bring to our work our individual histories and a shared history of colonization. Living in a colonizing society, we struggle to overcome the pervasive and often overwhelming colonial forces that make their way into our work, so we find decolonizing ourselves and our research methods challenging yet critical.

One of the tensions that arose during our research was the difference in expectations and requirements between the university and community. The university researchers wanted to support the work of the health services and thought that having our research assistants embedded in the health services office would accomplish that, which it did because they became aware of the day-to-day issues in the community. Unfortunately, as university researchers who were busy with our other duties, we were sometimes not clear about the requirements of the research with the community research assistant. For example, if consent forms are not prepared, approved by ethics, filled out, and signed (often parent or guardian permission is required), we cannot use any of the photographs, interview recordings, or other feedback from participants as data. So from the university perspective, consent forms are high on the list of priorities. From the community perspective, staff faced youth health concerns on a daily basis. Youth suicide, for instance, impacts not just the 
youth but also the staff and the entire community as everyone deals with the profound feelings of loss, guilt, and anger. Programming to lift the spirits of the youth becomes a priority while research requirements such as consent forms can seem like an obstacle to encouraging participation.

Linda: It just really highlighted the two different perspectives that come to a collaborative partnership.... We have people committing suicide. We need to do something to get out there and help these youth, and us at the university [were] kind of saying you know we have obligations to our funders that are important.

Despite our commitment to work together in an equitable manner, organizational structures and institutional hierarchies predisposed our collaborative work to power imbalances that could only be overcome through concerted efforts. In meetings, the university personnel would often outnumber the community members, which meant that university personnel took more space in the conversation. Decisions were not always based on equity of input. Also, university personnel were often perceived by others to have more status and power in decision-making, and to some extent, that was the case because funding for the program flowed from the university to the tribal council. At the same time, if the university personnel were not following the lead of the community when it was important to do so, the community could pull out of the agreement and shut down the research project.

Navigating among the demands of funding bodies, university research ethics boards, and the needs of the community can be fraught with challenges. In striving to Indigenize and decolonize our work, the structure of grants to the university can be one such challenge. A significant portion of our funding goes to training graduate students and capacity building in the community. Capacity building is an important part of the outcomes so that the community is richer for having undertaken the collaboration (Ball \& Janyst, 2008; Fletcher, 2003; Styres et al., 2010; Tobias et al., 2013), but it can be challenging when the time needed to commit to it is limited. Graduate students, especially those at the doctoral level, came to us with the research skills needed by the project, but they often lacked the knowledge and experience in Indigenous, decolonizing methods of research. For the community researcher, it was difficult to find a person both skilled at working with youth in the arts who also understood the research and the collaborative nature of our project. At times, we may not have been explicit enough in our expectations or did not have the time to adequately prepare team members for the complexity of our project.

New members to the team also brought their colonial baggage with them into the project, which affected their ability to participate as equal partners. 
Heather: When I was hired [as] research assistant on this project, I didn't actively bring those values and beliefs of [shared leadership] ... to the table for a long time because I brought my experience in academia ... [where] there tends to be a hierarchy. Research assistants are generally at the bottom of the team. They're the servants of the team.... For the first full year, I wondered what does it mean to assist in this group.... It really wasn't until my husband [who is Aboriginal] sort of said, "Heather, it's a circle. It's grounded in Aboriginal teachings," which is the way he had been interpreting it.... He said, "Everyone is equal. Everyone has a contribution to make, and if you're not making a contribution, you are just taking from the group." And I realized that sitting with my mouth closed and waiting to be told what to do meant that I was a taker and I wasn't a contributor in the group. So that was a click moment for me. It took me a good year of just sort of sitting and trying to figure out that the way we collectively seem to believe the world should be was also a way that academic research could be.

Academia's linear and hierarchical structure, with terms such as principal investigator, goes against the collaborative approach and requires partners in Indigenous research to decolonize their minds or socialize themselves to Indigenous ways of seeing the world (Absolon, 2011; Styres et al., 2010).

Another challenge is not to let the theatrical method we based our work on take over as the way to engage in the arts. Arts-based methodologies can be as disempowering as other research methods when they are imposed in a way that leaves little opportunity for participants to direct the process or safely express their authentic voices. In a critique of some theatre practice, Cherokee theatre practitioner Quo-Li Driskill (2008) wrote that theatre practitioners need to avoid entering communities and disregarding the artistic or theatrical traditions already in place, that, in other words, would replicate the colonizer-colonized relationship too often present when working with Indigenous communities. He underlined that a decolonization of bodies/minds/spirits is "inseparable from sovereignty, self-determination, land redress and the healing of our land bases" (p. 165). We work to remain mindful in our research activities of the importance of keeping activities structured flexibly so that youth can imaginatively pursue their own unique ideas.

Working in an alliance and partnership with otootemitowin (respectful openness and acceptance of others) brings challenges, not just to the research team, but to the research process itself. The embodied and emergent nature brought to the research by otootemitowin makes it difficult when applying for funding. Funding agencies often want to know specifics of planned activities and evidence or results of our 
work. Although we have questions we are investigating and have a plan of what we want to do, we remain open in our interaction with the communities to determine our specific course of action. Because we were working with a tribal council that includes several communities, we informed the communities of our research and responded to those who asked us to offer research workshops in their community, often communicated through the FHQ health educator or our research assistant.

Academic structures and advancement processes reward quick research and not the extended involvement required of Indigenous community-based research (Styres et al., 2010). For example, although our team writes collaboratively about our work, the structure of the university encourages individualism and gives recognition to "productive" academics. There is pressure to produce individually authored papers, whereas we insist that at least one community representative is a co-author and is listed as such to ensure our analysis reflects an Indigenous, noncolonial view of the community. Furthermore, practicing otootemitowin (respectful openness and acceptance of others) in our communication and methods is more time consuming than working in the conventional hierarchical manner of academia.

\section{Completing the Braid and Beginning Another: Concluding Thoughts}

Sweetgrass is the hair of our Mother; separately, each strand is not as strong as the strands are when braided together. (Objibwe' elder Mary Ritchie, 1995)

Our initial research project has grown and expanded. What started with drama workshops with youth in the FHQ region expanded into a visual arts program integrated with high school art classes, digital storytelling with urban youth, and annual "tipi camps" that integrate drama activities into an outdoor, land-based setting. In 2014, we expanded our arts-based research activities into a new community. This second community is a more remote First Nation school in northern Saskatchewan. We have established a high school drama program that students can take for credit and an extracurricular drama club for junior high school students. As anticipated, our lessons from our work in the South are both the basis of, and transformed by, the work in this new community.

Passion and commitment to this work keeps it going. It also helps that we have all become friends in the process. Humour is important to the building of relationships and a productive research process (Ball \& Janyst, 2008), and it is a constant presence in our working relationship, emerging in every team meeting, even the team interview. 
Nuno: What do you think sustains the project and has sustained its longevity for so long? The collaboration has been very fruitful, so what's the secret?

Heather: Fun.

Jo-Ann: An absolute belief in the work. A belief in the arts. A belief in the theatre work. A belief in the kids. Hope.

Warren: Continuous learning.

Jo-Ann: I really like everybody. I don't want to get a divorce [from the team].

Heather: I am not getting my dissertation done, but I don't want to quit this.

Karen: Liking each other is definitely part of it. I look forward to ... these meetings, which I don't [with] a lot of the other meetings I go to.... I like the research because to me it combines research with community service. I feel like we're doing something ... that is supporting the kids in charting their life path. When you see the need out there, that's partly too what sustains me... Poverty is a lack of resources, and when you look at the resources of First Nation communities, they have them, but often they're not aware of them. [Their resources are] very different than the ...rich, material goods and material services. First Nation communities are ... I think often ... not aware of their own richness, and so I think the work we do illuminates a lot of those complexities.

The metaphor of braiding the sweetgrass truly identifies what this project has become. We are three strands - university researchers, youth, and the FHQTC that have become woven together under a common goal. In "Braiding Sweetgrass: Indigenous Wisdom, Scientific Knowledge and the Teachings of Plants," Robin Wall Kimmerer (2013) developed a case for "cultures of regenerative reciprocity" (p. 377). As we strive to Indigenize the methods we use in our research project, it is important that we strive to think in similar relational terms. The development, maintenance, and renewal of social relationships, built on Indigenous concepts, are central to research with Indigenous people.

\section{Acknowledgments}

We acknowledge the work of postdoctoral scholar Nuno Ribiero, doctoral research assistant Heather Ritenburg, and community research assistant Alison Whiteman for their contributions to this article. This research was made possible with funding from the Canadian Institutes for Health Research Institute for Aboriginal Peoples' Health 
and the Saskatchewan Health Research Foundation. We thank the Indigenous youth participants who shared their talents and ideas to stimulate our thinking about health. We are also indebted to the elders for their support and File Hills Qu'Appelle Tribal Council for its willingness to partner with us and integrate our research project into its youth health initiatives.

\section{Note}

1. Cree words used in the article are in the dialect of Keith Goulet, who is a fluent Nehinuw (Cree) speaker and scholar from the "N" dialect speaking community of Cumberland House, Saskatchewan. For further details on the Cree terms and writing system used, see L. Goulet and K. Goulet (2014).

\section{References}

Absolon, K. [Minogiizhigokwe]. (2011). Kaandossiwin: How we come to know. Black Point, Canada: Fernwood.

Allan, B., \& Smylie, J. (2015). First peoples, second class treatment: The role of racism in the health and well-being of Indigenous peoples in Canada. Toronto, Canada: The Wellesley Institute.

Aluli Meyer, M. (2008). Indigenous and authentic: Hawaiian epistemology and the triangulation of meaning. In N. K. Denzin, Y. S. Lincoln, \& L. T. Smith (Eds.), Handbook of critical and Indigenous methodologies (pp. 217-232). Thousand Oaks, CA: Sage.

Ball, J., \& Janyst, P. (2008). Enacting research ethics in partnerships with Indigenous communities in Canada: "Do it in a good way." Journal of Empirical Research on Human Research Ethics, 3(2), 33-51. doi:10.1525/jer.2008.3.2.33

Barndt, D. (2009). Touching minds and hearts: Community arts as collaborative research. In G. J. Knowles \& A. Cole (Eds.), Handbook of the arts in qualitative research: Perspectives, methodologies, examples, and issues (pp. 351-362). Thousand Oaks, CA: Sage.

Bishop, R. (2011). Freeing ourselves from neo-colonial domination in research: A Māori approach to creating knowledge. International Journal of Qualitative Studies in Education, 11, 199-219. doi:10.1080/095183998236674

Canadian Institutes of Health Research. (2014, December). Tri-council policy statement: Ethical conduct for research involving humans (TCPS2). Ottawa, Canada: Author.

Driskill, Q.-L. (2008). Theatre as suture: Grassroots performance, decolonization and healing. In R. Hulan \& R. Eigenbrod (Eds.), Aboriginal oral traditions: Theory, practice, ethics (pp. 155-168). Winnipeg, Canada: Fernwood.

Episkinew, J. (2011, February 10). Re: Indigenizing university administration or Tâwaw cî? (Take 2) [Web log message]. Retrieved from http://www.ideas-idees.ca/blog/ indigenizing-university-administration-or-tawaw-ci-take-2

Findlay, I. M., Ray, C., \& Basualdo, M. (2014). The ethics of engagement: Learning with an Aboriginal cooperative in Saskatchewan. In B. Jeffery, I. M. Findlay, D. Martz, \& L. Clarke (Eds.), Journeys in community-based research (pp. 29-49). Regina, Canada: University of Regina Press. 
Fletcher, C. (2003). Community-based participatory research relationships with Aboriginal people in Canada: An overview of context and process. Pimatisiwin, 1(1), 27-61.

Goulet, L., \& Aubichon, B. (1997). Learning collaboration: Research in a First Nations teacher education program. In H. Christiansen, L. Goulet, C. Krentz, \& V. Maeers (Eds.), Recreating relationships: Collaboration and educational reform (pp. 115-128). Albany: State University of New York Press.

Goulet, L., \& Goulet, K. (2014). Teaching each other: Nehinuw concepts and Indigenous pedagogies. Vancouver, Canada: UBC Press.

Healy, G., \& Tagak, A., Sr. (2014). PILIRIQATIGIINNIQ "Working in a collaborative way for the common good": A perspective on the space where health research methodology and Inuit epistemology come together. International Journal of Critical Indigenous Studies, $7(1), 1-14$.

Jones, K., Gergen, M., Guiney Yallop, J. J., Lopez de Vallejo, I., Roberts, B., \& Wright, P. (Eds.). (2008). Performative social science [Special issue]. Forum: Qualitative Social Research, 9(2). Retrieved from http://www.qualitative-research.net/index.php/fqs/issue/view/10

Kimmerer, R. W. (2013). Braiding sweetgrass: Indigenous wisdom, scientific knowledge, and the teachings of plants. Minneapolis, MN: Milkweed Editions.

Knowles, J. G., \& Cole, A. L. (Eds.). (2008). Handbook of the arts in qualitative research: Perspectives, methodologies, exemplars, and issues. Thousand Oaks, CA: Sage.

Linds, W., Sammel, A., \& Goulet, L. (2013). Dancing together: A conversation about youth and adult relational authority in the context of education. International Journal of Child, Youth and Family Studies, 4, 337-356. doi:10.18357/ijcyfs43201312432

Linds, W., \& Vettraino, E. (2008). Collective imagining: Collaborative story telling through image theater. Forum: Qualitative Social Research, 9(2), Art. 56.

McNiff, S. (1998). Art based research. London, England: Jessica Kingsley.

Ritchie, M. (1995, October 8). Sweetgrass [NATIVE-L archive]. Retrieved from https://web. archive.org/web/20001011033958/http://nativenet.uthscsa.edu/archive/nl/9510/0086. html

Ritenburg, H., Young Leon, A. E., Linds, W., Nadeau, D. M., Goulet, L. M., Kovach, M., \& Marshall, M. (2014). Embodying decolonization: Methodologies and Indigenization. AlterNative: An International Journal of Indigenous Peoples, 10, 67-80.

Rossiter, K., Gray, J., Kontos, P., Keightly, M., Colantonio, A., \& Gilbert, J. (2008). From page to stage: Dramaturgy and the art of interdisciplinary translation. Journal of Health Psychology, 13, 277-286. doi:10.1177/1359105307086707

Skingley, A., Bungay, H., \& Clift, S. (2012). Researching participatory arts, wellbeing and health. Journal of Arts and Communities, 3, 73-87. doi:10.1386/jaac.3.1.73_1

Smith, L. T. (1999). Decolonizing methodologies: Research and Indigenous peoples. New York, NY: Palgrave.

Styres, S., Zinga, D., Bennett, S., \& Bomberry, M. (2010). Walking in two worlds: Engaging the space between Indigenous community and academia. Canadian Journal of Education, 33, 617-648. doi:10.2307/canajeducrevucan.33.3.617

Tobias, J. K., Richmond, C. A. M., \& Luginaah, I. (2013). Community-based participatory research with Indigenous communities: Producing respectful and reciprocal research. Journal of Empirical Research on Human Research Ethics, 8, 129-140. doi:10.1525/jer. 2013.8.2.129

Wilson, S. (2008). Research is ceremony: Indigenous research methods. Halifax, Canada: Fernwood. 


\section{About the Authors}

Janice M. Victor, Indigenous Peoples Health Research Centre; Linda M. Goulet, Indigenous Education, Health, and Social Work, First Nations University - Northern Campus; Karen Schmidt, File Hills Qu'Appelle Tribal Council Health Services; Warren Linds, Applied Human Sciences, Concordia University; Jo-Ann Episkenew, Indigenous Peoples Health Research Centre; Keith Goulet, First Nations University.

Janice M. Victor is now at the Faculty of Health Sciences, University of Lethbridge. Karen Schmidt is now an independent community partner. Moreover, our research team was greatly saddened by the passing of our colleague Dr. Episkenew in February 20 I6. She was integral to our research and contributed to this article before she began her spirit journey.

Correspondence concerning this article should be addressed to Janice Victor, Faculty of Health Sciences, University of Lethbridge, Lethbridge, AB TIK 3M4. Email: janice.victor@uleth.ca 